\title{
Political Institutions and the Incidence of FDI in South Asia
}

\section{Mumtaz Hussain Shah ${ }^{1}$}

\begin{abstract}
This paper attempts to empirically analyse the potential effect of political institutions on the inward foreign direct investments (FDIs) in five developing nations from South Asia, namely, Pakistan, Nepal, India, Bangladesh and Sri Lanka. Making FDI implies committing resources for a long time in the host economy. Therefore, availability of stable political institutions is one of the essential foreign location requisites for the multinationals' operations. Analysing annual aggregate data for years 1970 to 2009 through random effect panel estimation technique it is found that institutional indicators which count the most for foreign direct investors in SAARC nations are democratic accountability, absence of military and religious influences in politics, corruption-free and honest public office holders, and efficient bureaucracy. The results clearly indicate that changes in institutional variables do not make a significant positive impact on inward FDIs when aggregate measures of political institutional efficiency are employed. However, when these collective measures are disaggregated to a more clearly focused set of factors, their increased effectiveness significantly leads to additional FDI inflows. These results suggest that the findings are robust to alternative proxies of institutional strength, but sensitive to using catch-all composite measures of institutions.
\end{abstract}

Keywords: SAARC economies, FDI, panel data, political institutions

JEL Classifications: F230, F550, F590

\section{Introduction}

The last twenty-five years have witnessed an overall surge of foreign direct investment (FDI) in developing nations (Shah, 2014). Cold war culmination in 1990, not only ensued rapid integration of the world economy but also slowing or drying up of aid flows to the developing world (Essers, 2013). For instance, the development aid to Sub-Saharan Africa came down from $\$ 17$ billion in 1990 to $\$ 10$ billion by 2003 (Asiedu, 2006). According to World Bank, WDI, (2010) for South Asia aid assistance

1 Assistant Professor, Institute of Management Studies, University of Peshawar. Email: shah_mumtaz@hotmail.com

\begin{tabular}{llll} 
ARTICLE HISTORY & & \\
31 Aug, 16 & Submission Received & 23 Sep, 16 & First Review \\
\hline 12 Oct, 16 & Revised Version Received & 15 Nov, 16 & Second Review \\
\hline 21 Nov, 16 & Revised Version Received & 5 Dec, 16 & Accepted
\end{tabular}


was $\$ 4.2$ billion in 1985 and $\$ 5.9$ billion in 2001 . The decrease in aid flows along with the dearth of local available funds made it imperative for the developing countries like the South Asian Association for Regional Cooperation (SAARC) member economies to lure overseas investors.

The long term commitment of FDI in the host economy makes the incessant existence of congenial business and commercial environment a necessary requirement. Any political volatility that may risk the continuity of the optimum multinational production conditions is abhorred by the investors from abroad (Durnev, Enikolopov, Petrova, \& Santarosa, 2015). Therefore, an established civil administrative set-up promising the steadiness of laws and rules governing the operations of multinationals is essential for current investors not only to stay but to attract others as well. Moreover, developed political and legal institutions eradicate corruption and make bureaucracy liable for their actions which facilitate multinationals to achieve a greater degree of operational independence to optimally utilise their resources (Campisi \& Sottilotta, 2016).

Political volatility may interrupt the prevailing economic, financial and business practices thus principally distressing overseas investment. Domestic political and civil chaos might get projected in the direction of foreigners, creating additional snags for foreign owned firms (Shah \& Faiz, 2015). Foreign direct investors will expect such vulnerabilities to be much lesser in a democratic regime with more egalitarian orientation, especially if its rhetoric is for enhancing international investment and multinational presence (Lee, Biglaiser, \& Staats, 2014). MNCs are expected to favour such regimes as they believe that their assets are shielded from predatory banditry of dictators. In this perspective the current paper analyses the effectiveness of the availability of stable political institutions on the investment choice of foreign direct investors in five developing countries from South Asia.

Constancy of congenial business conditions is likely to compensate for lack of natural resources (Morisset, 2000). Nonetheless, Nigeria and Angola, despite their unstable political and economic environments, are two of the most successful countries to host FDI in the Sub-Saharan Africa. This is because of their comparative location advantage in oil reserves, which seems to outweigh / compensate for their institutional instability (Asiedu \& Lien, 2011).

In this study through a random effect panel estimation method the effects of political institutions on FDI in Pakistan, India, Bangladesh, Sri Lanka and Nepal are investigated. Exploiting annual aggregate inward FDI data for the years 1970 to 2009 , it is found that changes in the institutional variables do not exert a significantly 
positive effect on inward FDI when catch-all ${ }^{2}$ collective measures of institutional efficiency are employed in the regressions (Shah, 2011b). However, when these composite measures are disaggregated into a more clearly focused set of factors, their increased effectiveness leads to additional FDI inflows (Kapuria-Foreman, 2007). Probably it is due to the fact that observable institutional variables, such as economic system or political orientation, are excessively rudimentary to capture the intrigues that help to shape policies and institutions that affect the business market variables (Baltagi, Demetriades, \& Law, 2009). This makes modelling FDI an arduous task, not only because so many variables intervene but also because quantifying variables such as quality of workforce, government institutions, bureaucratic interventions, prevalence of corruption and competitive economic climate is in general difficult. The analysis further complicates due to the fact that the optimal level of institutional specific variables varies from country to country.

The bulk of the research papers quantitatively dealing with the political factors affecting inward FDI employ a catch-all feature, thus, making it difficult or nearly impossible to infer the individual influences from it (Li, Liu, \& Jiang, 2015). Therefore, this paper adds to the existing literature by examining a quite extensive array of indicators for institutional strength such as internal conflicts, external conflicts, government stability, extent of corruption, military in politics, religion in politics, law $\&$ order, ethnic tensions, democratic accountability and bureaucratic quality derived from the International Country Risk Guide (ICRG). Majority of these variables gauge the quality and strength of the current political institutions. However, corruption \& bureaucratic quality deals with transparency and efficiency of the state apparatus. The results manifest that among them the following indicators are significantly and positively associated with FDI inflows: Absence of corruption, efficient bureaucracy and an accountable democratic order that is free of military and religious influences.

The rest of this research paper continues in the following order. The relationship between political institutions with FDI inflows is discussed in section two. The incorporation of institutions in OLI paradigm is highlighted in section three and the data and estimation model are discussed in section four. Section five presents' empirical issues, results and analysis as well as the robustness checks. Section six concludes the paper.

\section{Institutions}

Institutions are defined as the humanly devised prevailing regulations that govern economic, political and social interactions among several players striving for their own interests and benefits (North, 1991). They provide the members of the society

2. Composite indexes used as a proxy for measuring institutional characteristics 
obeying these regulations with a predictable framework for dealing with one another (Ali, Fiess, \& Macdonald, 2010). According to Rodriguez, Siegel, Hillman, and Eden (2006), "excluding the role of host institutions from MNC's overseas activity is like taking out the 'national' out of 'inter-national"' (p. 734). Therefore, based merely on its relative edge in conventional FDI location factors a country may not be able to sustain its earlier strength of attracting FDI (Rios-Morales \& O'Donovan, 2006) with growing emphasis over improved efficiency in international production as one of the major FDI goals (Asiedu, 2004). This requires an actively positive role of the host government in the form of optimal business policies and political stability.

\subsection{Political Institutions \& Foreign Direct Investment}

Political consistency of democratic regimes generally ensures investors about government's commitment to credibly assist the functioning of economic entities (Dutta \& Roy, 2011). On the contrary, political volatility can ensue disorder which usually generates an adverse business climate, eroding the confidence of risk-averse overseas investors in the host economy's investment and commercial environment and drive them away (Quazi, 2007). This makes regime steadiness in the recipient country a significantly important factor concerning the host location choice for multinational investment decision.

Recognizing that democracy facilitates social harmony and political stability (Jensen, 2008b), foreign direct investors shall expect democracies to be less capricious towards their operations (Drury, Krieckhaus, \& Lusztig, 2006). Analysing 100 countries over the period 1970-1998, Jensen (2008a) finds that democratic countries attract 70 percent more FDI than non-democratic countries. Similarly, according to $\mathrm{Li}$ (2009) off the total 564 acts of expropriation around the globe committed between 1960-1986 only 59 took place in democratic countries and remaining 505 occurred under non-democratic regimes. The host's level of democracy is measured by the country scores from Polity IV project. These ratings are widely used in economics, political sciences, business and international relations research (Alcacer \& Ingram, 2008). This measure comprises of two 10 point indexes: a negative one for despotic characteristics, whilst a positive one for egalitarian qualities. Combining the two will give an index ranging from -10 for highly autocratic to +10 strongly democratic; therefore, it is recoded from 0 to 20 , with democratic countries getting better scores. This also allows for log transformation and makes further interpretation of the results easier. The polity IV ratings starts at 1800 and are used by Simmons and Hopkins (2005), Kwok and Tadesse (2006), Woo and Heo (2009), Kucera and Principi (2014), Garriga (2016) and Slimane, Huchet-Bourdon, and Zitouna (2016).

Popular political involvement encourages participative mentality which as a 
consequence leads to elimination of the vested interests and privileges being granted to a few ( $\mathrm{Li}, 2009)$. According to Jensen (2008b) firms in Singapore can respond to proposed legislative changes that may adversely affect their operations through the Singapore Economic Development Board (SEDB). It serves as an excellent legal formal institution ensuring that feedback of the business community and their concerns are addressed before any new legislation.

Political pluralism grants the protection of civil liberties and the extension of basic freedoms for everyone. These are virtues that engender the belief of individual prosperity; necessary for inspiring the populace to work, save, and invest - attitudes that are essential for successful, popular, effective and efficient governments. Overall, political freedom and civil liberties acts to liberate energies and cultivate entrepreneurial and economic conditions conducive for investors and producers. In order to gauge the extent of personal freedom the country ratings by Freedom House are also used. The original rating consists of two categories: political rights and civil liberties each varying from 1 to 7 , and their composite, with higher values indicating fewer rights. They are rescaled in reverse order so that more liberties and free populace are represented by higher points on a scale of 10 . The variable political rights exhibit the ability of the community to freely take part in the political process, as well as freely exercising the universal right to vote and contend for any office, civic or public, including electing representatives. Civil liberties express the liberty to cultivate opinions, develop institutions, individual independence and autonomy sans state interference. The ratings are available since 1972 and the 2010 Freedom House annual report covers 194 countries. The Freedom house country ratings are empirically employed by Harms and Ursprung (2002), Adam and Filippaios (2007), Feeny, Iamsiraroj, and McGillivray (2014) and Nagel, Herzer, and Nunnenkamp (2015), among many others ${ }^{3}$.

The two measures discussed above are considered reasonable and broadly comparable indicators of political freedom, civil liberties and electoral democracy but their aggregate nature requires the use of more precise and specific measures (Garriga, 2016). Therefore, to further gauge the expected effect of political stability on FDI inflows, in a comprehensive manner government stability, internal conflicts, external conflicts, military \& religion in politics, law \& order, ethnic tensions and democratic accountability measuring the Political Risk Components from the International Country Risk Guide (ICRG), are also used ${ }^{4}$. It is expected that a host country is likely to receive more FDI the more democratic and liberal it is, theorizing that countries with high levels of political risk and autocratic regimes will attract less investment, as

3. For details on the methodology, definition, rating etc. visit: http://www. freedomhouse.org.

4. Details on the methodology, definition, rating etc. are available at: $h t t p: / / w w w . p r s g r o u p . c o m / w p-c o n-$ tent/uploads/2012/11/icrgmethodology.pdf. The ICRG data is available from 1984 onwards therefore, it will cause a loss in the total number of observations. 
political instability renders economic and political context unpredictable and makes a country less attractive for FDI (Godinez \& Liu, 2015).

Dictatorial and despotic political cultures lack transparency and the rulers undermine the rule of law at personal whims. This destroys economic institutions, cause public office abuse and increases bureaucratic corruption. On the contrary, a democratic political culture nurtures open societies with the right governing set of checks and balances promulgated for limiting vagrant activities of political actors whereby they are less prone to misuse of public office (Kwok \& Tadesse, 2006).

Politicians have to weigh the costs of an illicit act in the presence of a responsive liberal society, who can remove them (Jensen, 2008a). Therefore, both the level of public office exploitation and corruption are lower under a democratic order and it is basically the lack of strong democratic institutions that corruption represents.

Consequently, the following hypotheses are set to answer the research question

$\mathrm{H}_{0}$ : The presence of superior political institutions does not affect investors' FDI choice.

$\mathrm{H}_{1}$ : The presence of superior political institutions positively affects investors' FDI choice.

\section{Institutions and the FDI Theories}

In early eighties theorists started incorporating multinationals into their models of international trade based on industrial organisation approach, with increasing returns to scale and imperfect competition. However, theoretical underpinning of FDI is, to a certain extent, still fragmented, gathering bits and pieces from different fields of business and economics to elucidate the pattern of multinationals overseas investments (Driffield \& Karoglou, 2016). In the following sub-section, a short preamble for using Dunning's Ownership, Location and Internalisation (OLI) paradigm is presented.

\subsection{Institutions and the Eclectic OLI Paradigm}

Earlier research concerning foreign direct investment flowing to the nations from the developing world has not addressed the role of political institutions in effecting overseas investors host location choice (Li \& Resnick, 2003). Despite the important association of host institutions with the long term characteristic of FDI, surprisingly, the possible influences of strong and vibrant political institutions on FDI in developing countries is somewhat understudied (Kawai, 2009). However, the increased worldwide economic integration partly due to intensified global multinational production 
especially in the developing nations (Dunning \& Lundan, 2008) have led to a greater recognition of the significance of institutions in the changing international business environment (Jensen, 2008b). Therefore, the new found focus on institutions does not seem unexpected (Gelbuda, Meyer, \& Delios, 2008) especially following the two decades of 1990's and 2000's (Ali et al., 2010). Empirical researchers of management, MNC's behaviour, international commerce and economics have started incorporating institutional variables into Dunning's OLI paradigm in investigating the role of institutions in influencing investor's location choice ${ }^{5}$.

One reason for the earlier neglect may be the inability of the major industrial organisational FDI theoretical frameworks initiated by Hymer's in 1960 to incorporate the volatility of policies in the host FDI country ${ }^{6}$.

These theories were developed keeping in mind the advanced Western European or North American countries where multiparty parliamentary democracies prevail in the political domain and established business ethics are practiced by the multinational and domestic firms. Incidentally the key industrial organisational FDI theories like Vernon's four step product life cycle hypothesis ${ }^{7}$ and Rugman (1986) or Teece (1985) internalisation theory have limited logical power to explain multinational's global production activity in the context of the SAARC countries, where, except for India, there has been an irregularity of policies due to regime changes between democratic and dictatorial set ups ( $\mathrm{Li}, 2009)$. This constant change of governing principals limits multinationals' ability to accurately forecast budgetary needs in accordance with predictable tax schedules and foreseeable future macroeconomic environment (Jensen, 2008a). Consequently, they are unable to mitigate any possible adverse policy shifts. Due to high sunk costs, FDI is especially vulnerable to any form of policy reversals (Bénassy-Quéré, Coupet, \& Mayer, 2007).

In the sense of institutions these theories were deficient to explain why investors choose to exploit relevant assets in a particular country and not in another one. However, because of its dynamism and flexibility Dunning's eclectic OLI paradigm can be utilised to explain the availability of better institutions under the broader context of the location $(L)$ advantages offered by the host economy (Godinez \& Liu, 2015). This is also because the eclectic paradigm encompasses a mixture of competing explanations including Hymer's industrial organisation approach, Vernon's trade and location theory and Teece or Rugman's transaction cost economics approach and so

5. For details over the OLI paradigm i-e Ownership $(O)$, Location (L) and Internalisation (I) see Dunning (2001, 2003, 2006 and 2009), whereas for incorporating explicitly institutions into it read Dunning and Lundan (2008).

6. For details see Hymer (1968, 1970, 1976), Hymer and Resnick (1969-1970) and Dunning and Rugman (1985).

7. For details on Product Life Cycle Hypothesis, see Vernon (1966, 1979, 1994) and Giddy (1978). 
on. For earlier incorporation of institutions into the eclectic OLI paradigm read Li and Resnick (2003), Asiedu (2004), Cuervo-Cazurra (2006), Rodriguez et al. (2006), Kawai (2009), Ali et al. (2010), Wilson and Baack (2012), Godinez and Liu (2015) and Vogiatzoglou and Tsekeris, (2016).

\section{Empirical Model and Data}

The choice of foreign production location by a multinational is primarily determined by the best possible combination of MNC's owned resources and the likely benefits from the overseas site. The investment climate that the multinationals are expected to face is directly associated with the host's quality of political and investment institutions. The qualitative nature of the institutional specific variables makes it fairly difficult to establish a standard estimation model. Moreover, in addition to institutional factors an indefinite mix of conventional location variables influence multinational's investment decision. Using the OLI theory and making use of the demand side elements along with the institutional influences, it is assumed that the effect of host institutional quality on inward FDI in South Asia from 1970 to 2009 can be estimated by the following general specification:

$$
F D I_{j t}=f\left(X_{j t} Y_{i j} Z_{j t}\right)
$$

Where $F D I_{j t}$ is the foreign direct investment from the rest of the world into the host country $j$ at time period t. $\chi_{j \mathrm{t}}$ are the macroeconomic variables representing the overall attractiveness of country $j$ to foreign direct investors. These include the size of the host market measured by gross domestic product (GDP) or population, development level or the state of human capital gauged by gross domestic product per capita (GDPPC) and openness of the local economy proxied by trade (imports plus exports of goods and services) as a percentage of GDP all collected from World Bank World Development Indicators. $Y_{i j}$ is the distance of the host from the source countries. $Z_{j t}$ stands for the institutional specific characteristics of the host country.

Implementing the investment function gives the following log-linearized specification

$$
\begin{aligned}
& \ln \mathrm{FDI} I_{j t}=a_{0}+\beta_{1} \text { lnMarketSize }_{j t}+\beta_{2} \ln \text { EconomicDevelopment }_{j t}+\beta_{3} \text { InOpenness }_{j t}+\beta_{4} \ln _{\text {Distance }} \\
& +\beta_{5} \text { Political Institutions }_{j t}+\xi_{j t}
\end{aligned}
$$

$\xi_{j t}$ shall cover for the omitted variables and is assumed to be normally distributed with a constant variance and zero mean. The rest of the variables are as explained earlier. In denotes natural logarithm. Log specification has shown the best adjustment to data in empirical literature (Daude \& Stein, 2007). In gravity models log-linearization reduces the heteroscedasticity in the error term (Habib \& Zurawicki, 2002). It is also preferred because by applying the natural logarithm the overall fit of the model also 
improves in comparison to the linear model (Busse, 2004).

Due to the aggregate nature of the dependent variable it is difficult to determine the source of the FDI; therefore, the distance variable is computed by taking the average of the distance between the host country and the leading outward FDI making countries in 2008. Including all the economies in distance calculation is useless because many small nations contribute negligibly to aggregate global outward FDI. If an economy's overseas investment for 2008 was more than US $\$ 5,000,000,000$ it is included. Consequently, it gives 55 economies with a gross foreign investment of US $\$ 207,386,469,370,844$, making $97.088 \%$ of 2008 world total outward foreign investment. These countries do not necessarily invest in South Asia but are the leading FDI exporters for 2008. The average distance was calculated as follows:

$$
\text { Distance }_{j}=\frac{\sum_{i=1}^{55} D_{i j}}{55}
$$

Where: $D_{i j}$ is the distance between each of the source countries $i$, that is each of the 55 leading outward FDI making countries in 2008 and the host country $j$. It is the population weighted distance between the most populous cities of $i$ and $j$ from Centre d'Etudes Prospectives et d'Informations Internationales (CEPII).

The average distance provides a standardised distance factor for each of the developing host South Asian economy with respect to all other countries in the world or their relative proximity with the world FDI source centres. The logic for including distance as one of the explanatory variables is that the extent of transportation cost is directly associated to distance. Consequently, if the nature of FDI is market seeking horizontal FDI, it will be positively affected by distance as FDI will substitute trade (Awokuse \& Yin, 2010). On the contrary, distance can have a negative effect on FDI inflows if it is vertical, where FDI and trade complement each other.

However, it needs to be remembered that distance is directly related to transaction cost in terms of information gathering and awareness of local market conditions. Market seeking FDI is driven by the size of the domestic market and income level of the host consumers (Asiedu, 2002) and the comparatively richer countries are optimal locations for market seeking horizontal FDI (Harms \& Ursprung, 2002). Due to the relatively low GDPPC of the sample countries, the increasing distance with FDI source countries is expected to exert a negative effect on their investment decision in the developing host economy. Therefore, the nearer a country is to the FDI source nation the higher shall be the level of FDI inflows. This argument depends on the significance of transaction costs for FD investors (Shah, 2017). Gravity models postulates that, FDI between two countries is weakened by the distance between them (Baltagi, Egger, \& Pfaffermayr, 2016). 
Bigger domestic markets of the FDI host nation (Morisset, 2000; Okubo, 2004; Awokuse \& Yin, 2010; Feeny, Iamsiraroj, \& McGillivray, 2014), its economy being reasonably developed (Coughlin, Terza, \& Arromdee, 1991; Adam \& Filippaios,

Table 1: Descriptive Statistics

\begin{tabular}{|c|c|c|c|c|c|}
\hline Name of the Variable & $\begin{array}{c}\text { Total Ob- } \\
\text { servations }\end{array}$ & $\begin{array}{c}\text { Aver- } \\
\text { age }\end{array}$ & $\begin{array}{c}\text { Standard } \\
\text { Deviation }\end{array}$ & $\begin{array}{c}\text { Smallest } \\
\text { Value }\end{array}$ & Highest Value \\
\hline lnFDI & 197 & 15.94 & 5.95 & 0 & 24.44 \\
\hline LnPopulation & 200 & 18.18 & 1.45 & 16.29 & 20.87 \\
\hline lnGDPPC & 200 & 5.71 & 0.66 & 4.29 & 7.83 \\
\hline lnTrade\%GDP & 200 & 3.51 & 0.5426 & 2.17 & 4.49 \\
\hline lnDistance & 200 & 8.84 & 0.07 & 8.72 & 8.95 \\
\hline Political Rights & 191 & 4.86 & 2.08 & 0 & 7.14 \\
\hline Civil Liberties & 191 & 4.17 & 1.18 & 2.86 & 7.14 \\
\hline PRCL & 191 & 4.51 & 1.52 & 1.43 & 7.14 \\
\hline Democ & 200 & 4.87 & 3.37 & 0 & 9 \\
\hline Autoc & 200 & 2.22 & 2.99 & 0 & 9 \\
\hline PolityIV & 200 & 12.65 & 6.21 & 1 & 19 \\
\hline Government Stability & 101 & 6.62 & 2.62 & 1.83 & 11.08 \\
\hline Democratic Account- & 101 & 3.51 & 1.51 & 0 & 6 \\
\hline ability & & & & & 0 \\
\hline Internal Conflict & 101 & 5.81 & 2.79 & 0 & 10.75 \\
\hline External Conflict & 101 & 8.42 & 2.37 & 4 & 12 \\
\hline Corruption & 101 & 2.21 & 0.95 & 0 & 4 \\
\hline Military in Politics & 101 & 2.52 & 1.67 & 0 & 5.75 \\
\hline Religion in Politics & 101 & 2.43 & 1.11 & 1 & 5 \\
\hline Law \& Order & 101 & 2.45 & 1.14 & 0 & 4 \\
\hline Ethnic Tensions & 101 & 2.13 & 1.43 & 0 & 5 \\
\hline Bureaucratic Quality & 101 & 1.99 & 0.83 & 0 & 3 \\
\hline & & & & & \\
\hline & 100 & & 0 \\
\hline
\end{tabular}

2007) and relatively open to foreign investment and encouraging world trade (Busse \& Hefeker, 2007; Dutta \& Roy, 2011) shall attract more foreign direct investment. Trade as a percentage of GDP can also be used to proxy the economic policy preferences of the host regime (Xing \& Wan, 2006) or the extent of the host country integration with the world economy (Roberts \& Almahmood, 2009; Shah, 2011a). Summary of the basic statistics for all the variables are given as Table 1 . 


\section{Estimation Issues, Data Analysis and Robustness Checks}

The data is arranged in a panel form because of having five countries for 40 years. The Hausman (1978) panel specification test was applied, to decide about the appropriate panel estimation technique. The following statistics $\operatorname{chi}^{2}(4)=3.32$ and Probability $>\mathrm{chi}^{2}=0.5061$ shows that the null hypothesis cannot be rejected therefore; the random effect method is used for empirical estimations.

Heteroscedasticity was confirmed by Breusch-Pagan / Cook-Weisberg test with $\operatorname{chi}^{2}(1)=49.14$ and Probability $>$ chi $^{2}=0.0000$. The Cameron and Trivedi (1990) information matrix test with $\operatorname{chi}^{2}(20)=41.61$, P-value $=0.0031$ also endorses heteroscedasticity. Hence, the robust option was employed with all the estimations to control for heteroscedasticity.

Table 2: Empirical Estimations Using Aggregate Measures of Institutional Quality

\begin{tabular}{|c|c|c|c|c|c|c|c|c|}
\hline \multicolumn{2}{|c|}{$\begin{array}{c}\text { Valuation Tech- } \\
\text { nique }\end{array}$} & \multicolumn{7}{|c|}{ Random Effects } \\
\hline Variables & Proxy & One & Two & Three & Four & Five & Six & Seven \\
\hline $\begin{array}{l}\text { Size of } \\
\text { Market }\end{array}$ & Ln POP & $\begin{array}{l}1.6205^{*} \\
(0.4095) \\
\end{array}$ & $\begin{array}{l}1.7828^{*} \\
(0.4277) \\
\end{array}$ & $\begin{array}{l}1.6181^{*} \\
(0.5837) \\
\end{array}$ & $\begin{array}{l}1.7250^{*} \\
(0.4932) \\
\end{array}$ & $\begin{array}{l}1.5753^{*} \\
(0.5104) \\
\end{array}$ & $\begin{array}{l}1.4130^{*} \\
(0.3859) \\
\end{array}$ & $\begin{array}{l}1.4899^{*} \\
(0.4641) \\
\end{array}$ \\
\hline $\begin{array}{l}\text { Devel- } \\
\text { opment } \\
\text { Level }\end{array}$ & $\begin{array}{c}\text { Ln GDP- } \\
\text { PC }\end{array}$ & $\begin{array}{l}3.9274^{*} \\
(0.6208)\end{array}$ & $\begin{array}{l}3.6727^{*} \\
(0.8289)\end{array}$ & $\begin{array}{l}3.8208^{*} \\
(0.9227)\end{array}$ & $\begin{array}{l}3.7322^{*} \\
0.8904)\end{array}$ & $\begin{array}{l}3.9507^{*} \\
(0.6759)\end{array}$ & $\begin{array}{l}4.0171^{*} \\
(0.6143)\end{array}$ & $\begin{array}{l}3.9898^{*} \\
0.6574)\end{array}$ \\
\hline $\begin{array}{l}\text { Open- } \\
\text { ness }\end{array}$ & $\begin{array}{l}\text { Ln } \\
\text { rade\% } \\
\text { GDP } \\
\end{array}$ & $\begin{array}{l}2.4624 \alpha \\
(1.1906)\end{array}$ & $\begin{array}{l}3.2115^{*} \\
(1.3896)\end{array}$ & $\begin{array}{l}2.9437 \alpha \\
(1.3559)\end{array}$ & $\begin{array}{l}3.0972 \alpha \\
(1.4221)\end{array}$ & $\begin{array}{c}2.3747 \phi \\
(1.3953)\end{array}$ & $\begin{array}{l}2.0147 \phi \\
(1.2118)\end{array}$ & $\begin{array}{l}2.1962 \phi \\
1.3250)\end{array}$ \\
\hline Distance & $\begin{array}{c}\text { Ln Aver- } \\
\text { age }\end{array}$ & $\begin{array}{r}-7.8667 \alpha \\
(3.8350) \\
\end{array}$ & $\begin{array}{l}-5.8732 \phi \\
(3.5653) \\
\end{array}$ & $\begin{array}{l}-7.6534 \\
(5.6729) \\
\end{array}$ & $\begin{array}{l}-6.4308 \\
(4.0685) \\
\end{array}$ & $\begin{array}{r}-8.1561 \alpha \\
(3.6645) \\
\end{array}$ & $\begin{array}{l}-9.2409^{*} \\
(2.8781)\end{array}$ & $\begin{array}{l}-8.7155^{*} \\
(3.2751) \\
\end{array}$ \\
\hline \multirow{3}{*}{$\begin{array}{c}\text { Freedom } \\
\text { House } \\
\text { (Freedom } \\
\text { of the } \\
\text { World) }\end{array}$} & $\begin{array}{l}\text { Political } \\
\text { Rights }\end{array}$ & & $\begin{array}{l}-0.0905 \\
(0.1615)\end{array}$ & & & & & \\
\hline & $\begin{array}{c}\text { Civil } \\
\text { Liberties }\end{array}$ & & & $\begin{array}{c}0.0964 \\
(0.4559)\end{array}$ & & & & \\
\hline & PRCL & & & & $\begin{array}{c}-0.0567 \\
(0.2277) \\
\end{array}$ & & & \\
\hline \multirow[t]{3}{*}{ Polity IV } & Democ & & & & & $\begin{array}{c}0.0224 \\
(0.1057) \\
\end{array}$ & & \\
\hline & Autoc & & & & & & $\begin{array}{c}-0.1241 \\
(0.1282) \\
\end{array}$ & \\
\hline & D\&A & & & & & & & $\begin{array}{c}0.0354 \\
(0.0596)\end{array}$ \\
\hline \multicolumn{2}{|c|}{ R-Squared } & $44.57 \%$ & $45.59 \%$ & $45.54 \%$ & $45.53 \%$ & $44.59 \%$ & $44.81 \%$ & $44.66 \%$ \\
\hline \multicolumn{2}{|c|}{ No of Observations } & 197 & 191 & 191 & 191 & 197 & 197 & 197 \\
\hline
\end{tabular}

Standard errors robust to heteroscedasticity are stated in parenthesis under the coefficient values.

* symbolizes significance at one percent, $\alpha$ at five percent and $\phi$ at ten percent. 
Models one to seven in Table 2 are in line with the established empirical results vis-à-vis multinationals fondness for the host country's large market size, their level of development and degree of openness. It also indicates their aversion for distant hosts. Openness, economic development and market size all have significantly positive coefficients and that for the average distance from the leading FDI exporters is significantly negative.

The coefficient for the distance variable was predicted to be dependent on the type of FDI. Distance increase the appeal for horizontal FDI to reduce trade costs but it also increases the organization and management costs. Similarly, the supply cost of raw materials and transport cost of finished goods in case of vertical FDI is directly proportional to distance. Likewise, openness may deter horizontal investors seeking market access but favours the vertical ones who require import of raw materials and export of finished goods. The positive sign for openness and negative one for distance collectively indicates the prevalence of vertical direct investment in South Asia. It was expected and seems natural given the relatively low GDPPC of all the five host countries which portrays labour wages and public purchasing power along with a country's overall development level.

The proxies for institutions from Freedom House and Polity IV are insignificant with the expected signs. Harms and Ursprung (2002) found a significant effect of political rights and civil liberties on FDI inflows. Their insignificance over here may be due to the aggregate nature of these proxies which makes them exceedingly loosely related to the phenomenon that affect the business market variables. Therefore, to further explore the effect of political institutions on FDI inflows the individual ratings for the indicators from ICRG are employed one by one, and the results are presented in Table 3.

Realising the fact that most of the variables measuring institutional factors have typically high correlation between them (Bénassy-Quéré et al., 2007) therefore, the ICRG measures are used one at time with the traditional FDI location determinants to avoid the possibility of multicollinearity (Biswas, 2002; Busse \& Hefeker, 2007). In model one, two and six of Table 3 it can be seen that law $\&$ order, ethnic tensions and government stability are insignificant. Nonetheless, steadiness of rules and regulations governing local and multinational firms is imperative as frequent government changes may cause short term regulatory vacuity which is abhorred by the foreign as well as local enterprise. Therefore, the possibility that it will have some ancillary positive effect cannot be ignored (Daude \& Stein, 2007). It can be seen by comparing the R square from Table 2 and Table 3 that the model's descriptive power straightaway increases from $45 \%$ to $64 \%$ when the ICRG measures are utilised instead of the composite country ratings. 
In model 3 it is clearly visible with the significant coefficient that higher democratic accountability induces additional inward FDI. This is expected because it makes politicians liable for their actions and enhances transparency in the state apparatus which is likely to foster a healthy economic environment that is not only ready to attract more FDI inflow, but also prepared to nurture the policy ingredients necessary for free market competition. It is also in accordance with Barro (2013) that fewer political rights negatively effects per capita growth. Which will decrease expected return on FDI, thus discouraging overseas investors.

However, Quazi (2007) on the contrary found that in democracies domestic firms by influencing politicians and bureaucrats make the business environment non-friendly for investors from abroad and China receives more FDI because it has a one party, iron fist, autocratic regime that though repressive of personal rights and individual liberties is very conducive for the interests and objectives of multinationals.

In model 8 and 10, the effect of corruption and bureaucratic quality on foreign investment is gauged. Both of them significantly influence investors from abroad. Analysing the results of model 3, $8 \& 10$ together it can be said that greater democratic accountability will force the governing regimes to keep a check on the bureaucracy and the extent and different forms/types of corruption. This is expected because democracy enjoys broad domestic support and due to public scrutiny they shall be less corrupt.

Model 7 and 9 confirms, that other things equal, the lesser is the role of military and religion in political set up of a host economy the greater is the inflow of overseas direct investment. Internal and external conflicts, law $\&$ order and ethnic tensions also have the anticipated effect, but while the signs are as expected, the variables generally do not reach conventional levels of significance.

The consistent significant negative coefficient for the distance variable validates that in the SAARC countries the additional monitoring costs of operating overseas affiliates that are directly associated with increasing distance outweigh the spatial trade (transport) cost.

Contrasting with Table 2, on the whole, a number of the disaggregated institutional variables are significant. The results for the disaggregated measures of institutional quality in Table 3 also indicate that the hypothesized relationship of a significant positive effect of political institutions on FDI inflows does hold.

The empirical results in Table 3 principally confirm and constitute quite persuasive evidence that in addition to structural variables such as development level, distance from the source, host market size and its degree of openness the presence and health of governing institutions are also important factors influencing FDI possibility. 


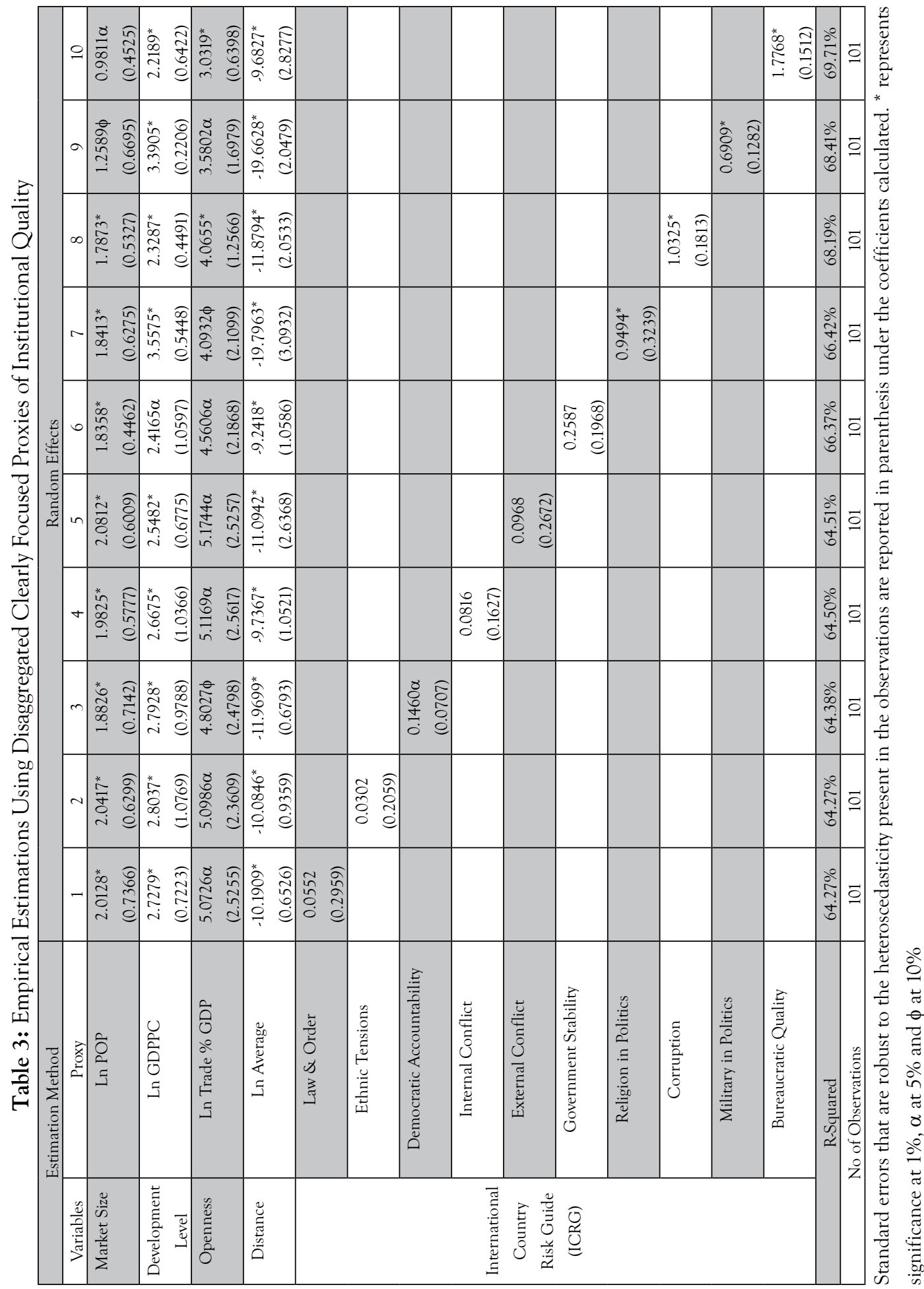


This is very much in accordance with the findings of Godinez and Liu (2015) that political instability significantly depresses and drives away FD investors. On the contrary, Biswas (2002) found a significant negative effect of democratic regime duration on FDI inflows from US in 44 countries, terming it "demoscelarosis" where a small interest group influences the decisions of democratic regimes for short term benefits. Similarly, Argentine experienced a military takeover in 1976 and received more FDI afterwards (Busse, 2004).

The results estimated so far suggest that better business environment in the host country, freer and large domestic market, absence of corruption, non-interference of military and religion in state affairs boost FDI inflows, while institutional dis-functioning and non-credible bureaucracy causes the contrary.

The disparity in the findings of Busse (2004) and the current paper may partly be due to the fact that the outward FDI from the developing countries has also increased manifold in the last few years, reaching over $\$ 100$ billion by 2005 (Sumner, 2008). It's plausible to expect that investors from OECD and developing countries are looking for different types of market characteristics and consequently, are paying attention to different set of policies and institutions in the host nation (Woo \& Heo, 2009; Godinez \& Liu, 2015). Mathews (2006) puts outward FDI of developing countries at more than $10 \%$ of world total outward FDI. According to Gao (2005) even in China $70 \%$ of FDI inflows are from developing countries.

While largely the results are consistent with the current FDI literature, still, this finding needs further attention and investigation by the contemporary researches analysing FDI inflows in the developing countries.

\section{Conclusion}

This paper analysed the effect of host nation political institutions in South Asia on foreign direct investment from the rest of the world. The empirical results of the paper are robust to alternative proxies for the institutional variables but not to catchall aggregate proxies of institutions. However, the traditional FDI determinants such as market size, development level/human capital, distance and openness of the host economy sustain their robustness.

Changing a country's image is time consuming especially when the subsequent regimes have a long tradition of adopting new texts that are seldom translated into tangible state action. Therefore, penchant for democratization and subjecting government to greater scrutiny and accountability from a broader segment of the general public will limit the abuse of public office ensuing transparency and efficiency in bureaucracy and engender free market competition in the economy that is conducive for equal 
investment opportunities for all, and which in turn can attract more FDI inflows.

When compared with the other regions like ASEAN, Latin America, CEEC or even the MENA countries, the amount of research on FDI in SAARC countries is limited. This paper is part of the initial efforts to analyse the inflow of FDI into SAARC and especially Pakistan, Nepal and Sri Lanka from the perspective of political institutional characteristics of the host economies. The divergence of results from the aggregate and the detailed ICRG data set indicates that some of the institutional determinants of inward FDI previously established for developed and developing countries as the target recipients of FDI do not necessarily hold for the SAARC countries namely: Bangladesh, India, Nepal, Pakistan and Sri Lanka.

The limitations of the study are acknowledged and it is expected that availability of micro level data over time shall certainly be of help to clear some of the muddy waters. My findings set forth some potential agenda for future research. For instance, an industry level analysis may provide insight over a possible variation in effects of institutional variables across industries. While it is evident from this paper that disaggregation of institutional variables yields conflicting results than aggregation, whether the former helps in ascertaining variation in optimal strength of FDI in South Asia linked to source countries, types of FDI and even type of firms rests open for future investigation.

\section{References}

Adam, A., \& Filippaios, F. (2007). Foreign direct investment and civil liberties: A new perspective. European Journal of Political Economy, 23(4), 1038-1052.

Alcacer, J., \& Ingram, P. (2008). Spanning the institutional abyss: The intergovernmental network and the governance of foreign direct investment. Harvard Business School.

Ali, F., Fiess, N., \& Macdonald, R. (2010). Do institutions matter for foreign direct investment? Open Economies Review, 21(2), 201-219.

Asiedu, E. (2002). On the determinants of foreign direct investment to developing countries: Is Africa different? World Development, 30(1), 107-119.

Asiedu, E. (2004). Policy reform and foreign direct investment in Africa: Absolute progress but relative decline. Development Policy Review, 22(1), 41-48.

Asiedu, E. (2006). Foreign direct investment in Africa: The role of natural resources, market size, government policy, institutions and political instability. The World Economy, 29(1), 63-77.

Asiedu, E., \& Lien, D. (2011). Democracy, foreign direct investment and natural resources. Journal of International Economics, 84(1), 99-111. 
Awokuse, T. O., \& Yin, H. (2010). Intellectual property rights protection and the surge in FDI in China. Journal of Comparative Economics, 38(2), 217-224.

Baltagi, B. H., Demetriades, P. O., \& Law, S. H. (2009). Financial development and openness: Evidence from panel data. Journal of Development Economics, 89(2), 285-296.

Baltagi, B. H., Egger, P. H., \& Pfaffermayr, M. (2016). Special issue on the estimation of gravity models of bilateral trade: Editors' introduction. Empirical Economics, 50(1), 1-4.

Barro, R. J. (2013). Democracy, law and order, and economic growth. In B. Riley \& T. Miller (Eds.), Index of economic freedom: No boost in trade freedom. (pp. 41-58). Washington, D. C.: Heritage Foundation and Dow Jones \& Company, Inc.

Bénassy-Quéré, A., Coupet, M., \& Mayer, T. (2007). Institutional determinants of foreign direct investment. World Economy, 30(5), 764-782.

Biswas, R. (2002). Determinants of foreign direct investment. Review of Development Economics, 6(3), $492-504$.

Busse, M. (2004). Transnational corporations and repression of political rights and civil liberties: An empirical analysis. Kyklos, International Review of Social Sciences, 57(1), 45-65.

Busse, M., \& Hefeker, C. (2007). Political risk, institutions and foreign direct investment. European Journal of Political Economy, 23(2), 397-415.

Cameron, A. C., \& Trivedi, P. K. (1990). The information matrix test and its implied alternative hypotheses. (No. 372). California Davis - Institute of Governmental Affairs.

Campisi, J. M., \& Sottilotta, C. E. (2016). Unfriendly or unwanted? Reflections on FDI attraction policies in Italy. Rivista Italiana di Politiche Pubbliche, 11(2), 223-250.

Coughlin, C. C., Terza, J. V., \& Arromdee, V. (1991). State characteristics and the location of foreign direct investment within the United States. The Review of Economics and Statistics, 73(4), 675-683.

Cuervo-Cazurra, A. (2006). Who cares about corruption? Journal of International Business Studies, 37(6), 807-822.

Daude, C., \& Stein, E. (2007). The quality of institutions and foreign direct investment. Economics and Politics, 19(3), 317-344.

Driffield, N., \& Karoglou, M. (2016). Brexit and foreign investment in the UK. Available at SSRN: https://ssrn.com/abstract=2775954

Drury, C., Krieckhaus, J., \& Lusztig, M. (2006). Corruption, democracy, and economic growth. International Political Science Review, 27(2), 121-136.

Dunning, J. H. (2001). The eclectic (OLI) paradigm of international production: Past, present and future. International Journal of the Economics of Business, 8(2), 173-190. 
Dunning, J. H. (2003). Some antecedents of internalization theory. Journal of International Business Studies, 34(2), 108-115.

Dunning, J. H. (2006). Towards a new paradigm of development: implications for the determinants of international business activity. Transnational Corporations, 15(1). 173-227.

Dunning, J. H. (2009). Location and the multinational enterprise: A neglected factor? Journal of International Business Studies, 40(1), 5-19.

Dunning, J. H., \& Lundan, S. (2008). Institutions and the OLI paradigm of the multinational enterprise. Asia Pacific Journal of Management, 25(4), 573-593.

Dunning, J. H., \& Rugman, A. M. (1985). The influence of Hymer's dissertation on the theory of foreign direct investment. The American Economic Review, 75(2), 228-232.

Durnev, A., Enikolopov, R., Petrova, M., \& Santarosa, V. (2015). Politics, instability, and composition of international investment flows. Journal of Corporate Finance, 30, 299-324.

Dutta, N., \& Roy, S. (2011). Foreign direct investment, financial development and political risks. The Journal of Developing Areas, 44(2), 303-327.

Essers, D. (2013). Developing country vulnerability in light of the global financial crisis: Shock therapy? Review of Development Finance, 3(2), 61-83.

Feeny, S., Iamsiraroj, S., \& McGillivray, M. (2014). Growth and foreign direct investment in the Pacific Island countries. Economic Modelling, 37, 332-339.

Gao, T. (2005). Foreign direct investment from developing Asia: Some distinctive features. Economics Letters, 86(1), 29-35.

Garriga, A. C. (2016). Human rights regimes, reputation, and foreign direct investment. International Studies Quarterly, 60(1), 160-172.

Gelbuda, M., Meyer, K. E., \& Delios, A. (2008). International business and institutional development in Central and Eastern Europe. Journal of International Management, 14(1), 1-11.

Giddy, I. H. (1978). The demise of the product cycle model in international business theory. Columbia Journal of World Business, 13(1), 90-97.

Godinez, J. R., \& Liu, L. (2015). Corruption distance and FDI flows into Latin America. International Business Review, 24(1), 33-42.

Habib, M., \& Zurawicki, L. (2002). Corruption and foreign direct investment. Journal of International Business Studies, 33(2), 291-307.

Harms, P., \& Ursprung, H. W. (2002). Do civil and political repression really boost foreign direct investments? Economic Inquiry, 40(4), 651-663.

Hausman, J. A. (1978). Specification tests in econometrics. Econometrica, 46(6), 1251-1271. 
Hymer, S. (1968). The large multinational corporation: An analysis of some motives for the international integration of business. Revue Economique, 19(6), 949-973.

Hymer, S. (1970). The efficiency (contradictions) of multinational corporations. The American Economic Review, 60(2), 441-448.

Hymer, S. (1976). The international operations of national firms: A study of direct foreign investment. Cambridge MA: MIT Press.

Hymer, S., \& Resnick, S. (1969-1970). The crisis and drama of the global partnership. International Journal, 25, 184-191.

Jensen, N. M. (2008a). Nation-states and the multinational corporation: A political economy of foreign direct investment. Princeton, NJ: Princeton University Press.

Jensen, N. M. (2008b). Political risk, democratic institutions, and foreign direct investment. The Journal of Politics, 70(4), 1040-1052.

Kapuria-Foreman, V. (2007). Economic freedom and foreign direct investment in developing countries. The Journal of Developing Areas, 41(1), 143-154.

Kawai, N. (2009). Location strategies of foreign investors in China: Evidence from Japanese manufacturing multinationals. Global Economic Review: Perspectives on East Asian Economies and Industries, 38(2), 117-141.

Kucera, D. C., \& Principi, M. (2014). Democracy and foreign direct investment at the industry level: Evidence for US multinationals. Review of World Economics, 150(3), 595-617.

Kwok, C. C. Y., \& Tadesse, S. (2006). The MNC as an agent of change for host-country institutions: FDI and corruption. Journal of International Business Studies, 37(6), 767-785.

Lee, H., Biglaiser, G., \& Staats, J. L. (2014). Legal system pathways to foreign direct investment in the developing world. Foreign Policy Analysis, 10(4), 393-411.

Li, C., Liu, H., \& Jiang, Y. (2015). Exchange rate risk, political environment and Chinese outward FDI in emerging economies: A panel data analysis. Economics World, 3(5), 145-155.

Li, Q. (2009). Democracy, autocracy, and expropriation of foreign direct investment. Comparative Political Studies, 42(8), 1098-1127.

Li, Q., \& Resnick, A. (2003). Reversal of fortunes: Democratic institutions and foreign direct investment inflows to developing countries. International Organization, 57(1), 175-211.

Mathews, J. (2006). Dragon multinationals: New players in $21^{\text {st }}$ century globalization. Asia Pacific Journal of Management, 23(1), 5-27.

Morisset, J. (2000). Foreign direct investment in Africa: Policies also matter. Transnational Corporations, 9(2), 107-126. 
Nagel, K., Herzer, D., \& Nunnenkamp, P. (2015). How does FDI affect health? International Economic Journal, 29(4), 655-679.

North, D. C. (1991). Institutions. The Journal of Economic Perspectives, 5(1), 97-112.

Okubo, T. (2004). The border effect in the Japanese market: A gravity model analysis. Journal of the Japanese and International Economies, 18(1), 1-11.

Quazi, R. (2007). Economic freedom and foreign direct investment in East Asia. Journal of the Asia Pacific Economy, 12(3), 329-344.

Rios-Morales, R., \& O’Donovan, D. (2006). Can the Latin American and Caribbean countries emulate the Irish model of FDI attraction? Revista de la CEPAL, 88, 49-66.

Roberts, B. M., \& Almahmood, A. (2009). Source country characteristics and the inflow of foreign direct investment into Saudi Arabia. World Economy, 32(12), 1730-1746.

Rodriguez, P., Siegel, D. S., Hillman, A., \& Eden, L. (2006). Three lenses on the multinational enterprise: Politics, corruption, and corporate social responsibility. Journal of International Business Studies, 37(6), 733-746.

Rugman, A. M. (1986). New theories of the multinational enterprise: An assessment of internalization theory. Bulletin of Economic Research, 38(2), 101-118.

Shah, M. H. (2011a). Bilateral linkages with OECD and FDI inflows in leading developing countries. International Journal of Interdisciplinary Social Sciences, 5(7), 255-270.

Shah, M. H. (2011b). Essays on foreign direct investment in developing countries. Doctoral dissertation, University of Leicester.

Shah, M. H. (2014). The significance of infrastructure for FDI inflow in developing countries. Journal of Life Economics, 2, 1-16.

Shah, M. H., \& Faiz, M. (2015). Terrorism and foreign direct investment: An empirical analysis of SAARC countries. City University Research Journal, 5(2), 219-233.

Shah, M. H., (2017). Significance of WTO's trade related investment measures (TRIMS) agreement for inward FDI in Sub-Saharan Africa. City University Research Journal, 7(1), 17-29.

Simmons, B. A., \& Hopkins, D. J. (2005). The constraining power of international treaties: Theory and methods. The American Political Science Review, 99(4), 623-631.

Slimane, M. B., Huchet-Bourdon, M., \& Zitouna, H. (2016). The role of sectoral FDI in promoting agricultural production and improving food security. International Economics, 145, 50-65.

Sumner, A. (2008). Foreign direct investment in developing countries: Have we reached a policy 'tipping point'? Third World Quarterly, 29(2), 239-253.

Teece, D. J. (1985). Multinational enterprise, internal governance, and industrial organization. The 
American Economic Review, 75(2), 233-238.

Vernon, R. (1966). International investment and international trade in the product cycle. The Quarterly Journal of Economics, 80(2), 190-207.

Vernon, R. (1979). The product cycle hypothesis in a new international environment. Oxford Bulletin of Economics $\mathcal{E}$ Statistics, 41(4), 255-267.

Vernon, R. (1994). Contributing to an international business curriculum: An approach from the flank. Journal of International Business Studies, 25(2), 215-227.

Vogiatzoglou, K., \& Tsekeris, T. (2016). Determinants of inward FDI in manufacturing: A cross-sectoral analysis for Greece. International Journal of Economics and Business Research, 11(4), 347-365.

Wilson, R. T., \& Baack, D. W. (2012). Attracting foreign direct investment: Applying Dunning's location advantages framework to FDI advertising. Journal of International Marketing, 20(2), 96-115.

Woo, J. Y., \& Heo, U. (2009). Corruption and foreign direct investment attractiveness in Asia. Asian Politics $\mathcal{E}$ Policy, 1(2), 223-238.

Xing, Y., \& Wan, G. (2006). Exchange rates and competition for FDI in Asia. World Economy, 29(4), 419-434. 
